\title{
A Study on Corporate Governance and Business Ethics: Indian Scenario
}

\author{
Dr. Pradip Kumar Das \\ Associate Professor \& Teacher-in-Charge, \\ Commerce Unit (Morning), J.K. College, Purulia \\ Affiliation under S.K.B. University, Purulia
}

\begin{abstract}
Frequent corporate frauds and governance failures dotting the global corporate map have witnessed comparably vigorous efforts of improving corporate governance practices. India has liberalized the regulatory fabric of the country to align her corporate governance norms with those of developed countries. And yet, achieving good governance and ensuring results of such governance practices continue to remain one of the top priorities of stakeholders even today. High profile scandals resulting in financial collapses have served as the impetus for most sweeping corporate governance practices for bringing economic viability to the nations. Abuse of authority by a particular group of stakeholders continues to influence the corporate choices to the extent stakeholders. Governance is no longer treated as a set of rules concerning the management of firm; rather, it would establish diverse rights and obligations to reduce the negative externalities of an economic entity. By this paper, the author intends to explain the gap between corporate governance reforms and ethics and to seek why these two movements seem yet to be generated little in the form of widely accepted prescriptions for improvement of business behavior to the satisfaction of the constituents of business. The implication of the study showcases conduct, measures to be taken to induce compliance with provisions of the code. It also suggests as to how regulatory bodies should deal with corporate overcoming the weaknesses concerning the way they conceive modern business operations in the event of non-compliance by corporate.
\end{abstract}

Keywords: Corporate governance, Business ethics, Business operation, Corporate, Stakeholders

\section{INTRODUCTION}

Nowadays, due to highly complex and collective affairs business involves the interests of not only a large number of investors but many other persons of society also. In the fast changing economic and social scenario, an intimate interaction between industries on the one hand and the society on the other has thus become absolutely necessary. Simply, corporate governance combined with ethics refers to a set of core principles followed by a corporate entity ensuring corporate transparency as well as accountability to their shareholders and other beneficiaries of the society for their actions. During the course of operations and activities, various types of corruption frequently occurring in the corporate world with their vicious effects on the organization and the society undervalue the importance of ethics in taking managerial decisions and the need for building an ethical environment in the interest of the success of the organization and well-being of the society develops. Of late, corporate governance and business ethics movements have been developed in many developed countries of the world including India as responses to a developing perception of corporate wrongdoings. The success of modern business is quite apparent; but, there is much concern in the business-andsociety literature and in the general press on whether business fulfills its social role responsibly [1]. 


\section{PROBLEM STATEMENT AND STUDY OBJECTIVE}

Corporate governance has enjoyed unprecedented attention around the globe. The relationship between corporate governance and business ethics has always been ambiguous. To understand this, three questions are explored in this paper to find out the answer:-

1) Does corporate governance have an ethical nature? 2) Is business ethics an integral part of corporate governance or is it marginalized? 3) Does corporate governance also include the governance of ethics? In this context, the intention of this paper is to study the corporate governance practices in India in the light of the Companies Act, 2013 and suggest measures to arrest such corruption. Installation of ethical values and standards into the goals, policies, strategies, plans and above all, the culture of the corporate has become absolutely necessary for building an overall environment for ethical management.

\section{LITERATURE REVIEW}

Good corporate governance practices help corporations and its stakeholders; to do so various audit committee mechanisms are required [2]. Research on corporate governance with respect to the emerging market is much needed. Various benefits of better corporate governance practices are noticed [3]. A corporate governance framework needs to be developed by providing a broad overview of recent corporate governance research. All aspects of corporate governance are important from board structure to ownership structure [4]. In most of the developing and developed countries, major corporate governance reforms took place. These reforms affected investor protection as well as impacted corporate investments [5]. The role of audit committee and its main function is to protect the auditor from dismissal in case of unfavorable report. Independent audit committee members experience a significant increase in turnover rate after auditor dismissals [6]. Corporate governance has become an important issue for China and India as they regularly interact with investors from developed countries [7].Various aspects of business ethics and its relation to corporate governance can be observed by understanding various issues related to corporate board of directors and the basis on which they are to be analyzed [8]. Ethics in corporate governance also plays an important role; operational dynamics of corporate governance are a necessary part of modern industrialization. An outline for matching the rules and practices of US corporate governance to different cultural methods can be provided [9].Schwartz analyses the managers' perception on the term "business ethics". He associates the term with elements of ethical behavior and non-ethical behavior [10].

\section{RESEARCH METHODOLOGY}

In an attempt to answer the research questions put forward in this study, the researcher has gone through the web pages and collected information from the reports published on corporate website on corporate governance and business ethics. The websites of these corporate are visited, and the text in the ethics policies \& corporate governance as stated on these websites are analyzed to serve as the input data for study. The study being conceptual and descriptive expresses the author's own opinion and opinion of some reputed authors. The work is designed for a cross-section of those for making the issue easily understandable and organized into several phases. First phase deals with conceptual view of corporate governance; second phase is concerned with business ethics; third phase shows Indian scenario; fourth phase suggests measures for sound corporate governance and finally, conclusion along with suggestion has been given. 


\section{FIRST PHASE}

\section{Salient features}

\section{CORPORATE GOVERNANCE - CONCEPTUAL VIEW}

The importance of corporate governance remains within clarity of vision, plan of action and execution of the plan of action. Dr. Manmohan Singh, Hon'ble ex-Prime Minister of India once said that whereas our policies and systems are good but the implementation needs much to be desired. Both ethics and corporate governance are required for stable sustainable growth and for this directors and promoters should come together to build a strong ethical culture for the company. The famous Cadbury Committee defined "Corporate Governance" in its Report (Financial Aspects of Corporate Governance, published in 1992) as "the system by which companies are directed and controlled". The Organization for Economic Cooperation and Development (OECD) published its Principles of Corporate Governance in 1999 provides a very comprehensive definition of corporate governance as:"a set of relationships between a company's management, its board, its shareholders and other stakeholders. Corporate governance also provides the structure through which the objectives of the company are set, and the means of attaining those objectives and monitoring performance are determined. Good corporate governance should provide proper incentives for the board and management to pursue objectives that are in the interests of the company and shareholders, and should facilitate effective monitoring; thereby encouraging firms to use recourses more efficiently."

Corporate governance tries to establish a particular relationship between corporation, shareholders and directors. The board acts as managers, trustees, employees,' etc. [11]. The relationship can be exhibited as follows:

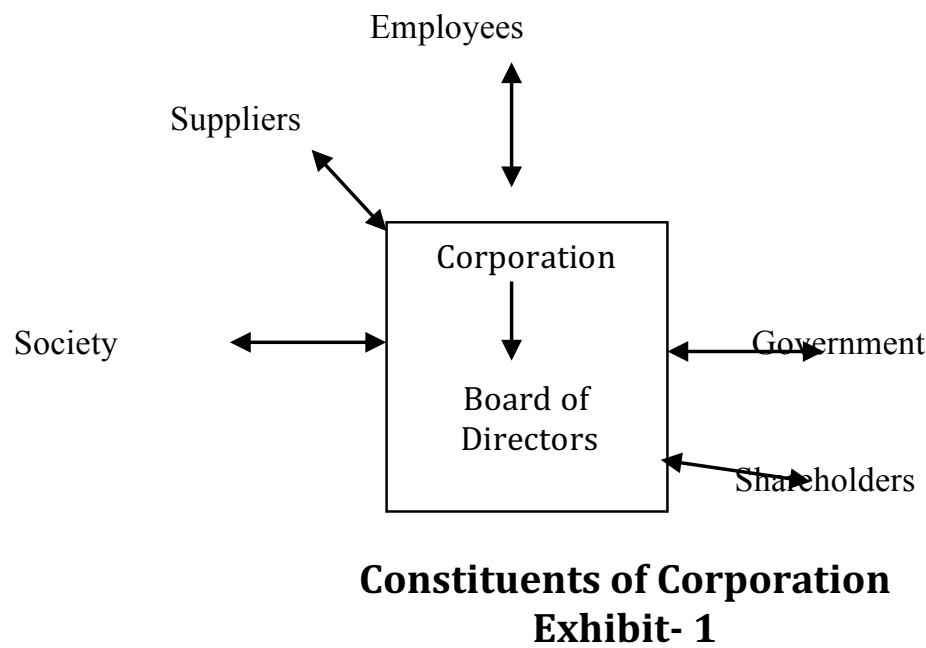

A transparent, ethical and responsible corporate governance framework emerges from the inherent will and passion for good governance engrained in the business entity. Mere legislation does not always ensure good governance; rather, ethical business practice without legislation may create good governance. Society provides the desired climate for successful operation of a corporate sector business. Business loses its faith in the eyes of stakeholders if society turns against the corporate. Good governed corporate sectors always value for the society in which they operate their business. Corporate sectors are required to understand the expectation of the society from them and should strive to provide maximum for the society according to its need. 


\section{Principles, Factors and Merits of Corporate Governance}

A country's culture, political orientation and its legal system affect corporate governance. Basically, good corporate governance consists of certain basic principles such as transparency, accountability, responsibility and finally fairness. This can be shown as:

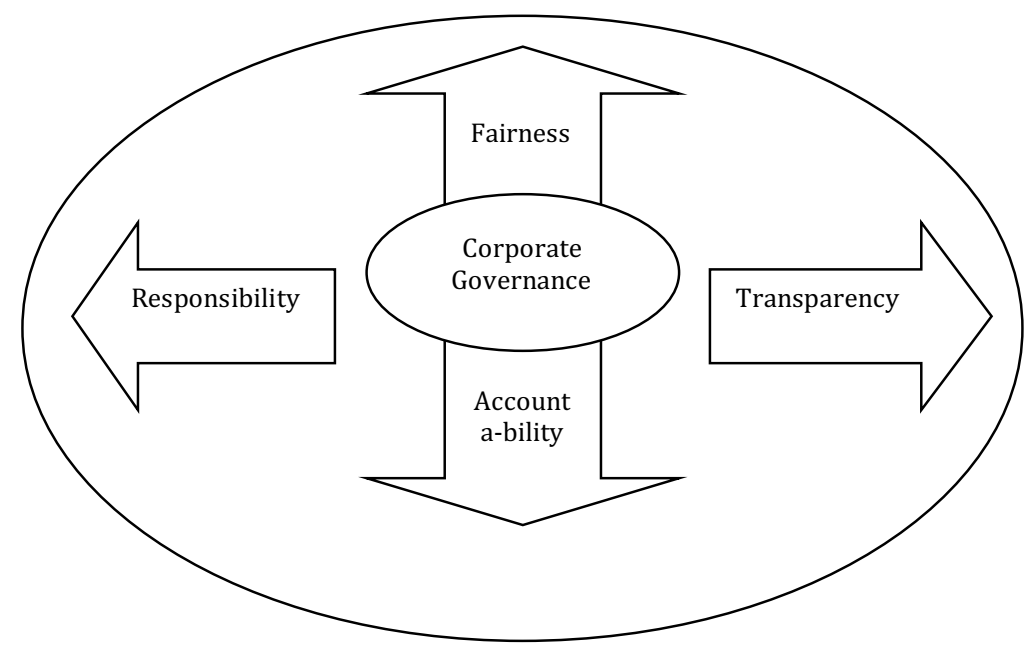

Exhibit-2

Ideally, corporate governance should attempt to create corporate consciousness and an environment so that genuine ethical, social and ecological responsibilities are displayed. In fact, corporate governance is the application of best management practices, compliance of law in true letter and spirit and adherence to ethical standards for effective management and distribution of wealth and discharge of social responsibilities for sustainable development of all stakeholders.

Corporate governance has certain factors viz. i) affirmation of right by the owners; ii) significant presence of foreign investors demanding highly professionalism in the management of Indian corporate sectors; iii) lending institutions claiming adoption of effective accounting standards and norms and iv) business environment for economic liberalization, globalization, etc.

Corporate governance is about commitment to values, ethical business conduct and making a distinction between personal and corporate funds in the management of a company. Key pillars of good governance include risk assessment and management, internal control systems ethics and fraud prevention strategy, and transparency and trust [12]. Sound corporate governance is the blood filling the veins of transparent corporate disclosure and high quality accounting practices. Like muscle, it moves a viable and accessible financial reporting structure. A business organization has social obligation and ethical duty to conduct in a lawful manner. Violating it may bring about its own liquidation [13]. In view of these, creating congenial atmosphere in the organization that fosters the practice of ethical behavior and principles is extremely important. 
Various stakeholders affected by the corporate governance practices can be shown as:-

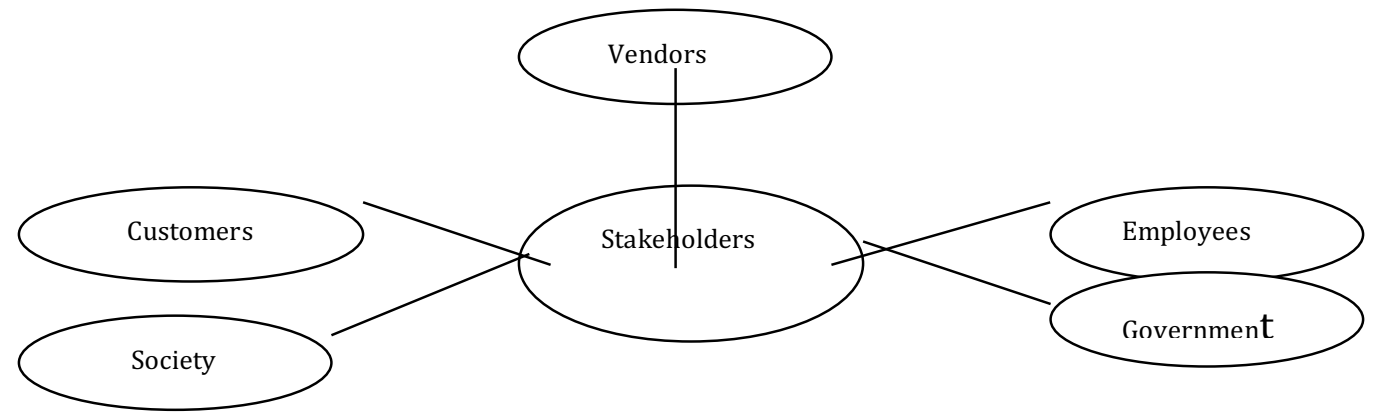

Exhibit- 3

Corporate governance demands the following merits viz. i) maximization of resource; ii) congruity of relationship between shareholders and managers; iii) goodwill and reputation; iv) durability; v) growth; vi) expansion and diversification; vii) supply of quality goods and services; viii) attractive managerial remuneration: ix) service to society and community; $x$ ) increase of revenue to government; xi) improvement of value added to government; xii) improvement of customer-company relationship; xiii) safety of performance of assets and resources conferred to management; xiv) improvement of EPS; xv) development of corporate disclosure practices; xvi) auditing practices; xvi) positive tax effect and xvii) better business combinations.

\section{SECOND PHASE}

\section{BUSINESS ETHICS - CONCEPTUAL VIEW}

Business ethics includes understanding the differences between right and wrong thinking and actions, and using principled decision making to choose actions that do not hurt others. Business ethics refers to the moral principles and standards and a code of conduct with expectation that businessmen should follow while dealing with others. Important issues in business ethics include ethical management of enterprise in relation to its stakeholders in particular and natural environment in general. It represents moral concern towards implementation of business processes in tune with the nobility of the purpose. All businesses having social responsibility has something to do with its ordinary economic activity. Responsibility towards society is a moral obligation arising out of business ethics, which in turn is steeped in the philosophy of business. An organization following ethical practices in all its activities will follow best corporate governance practices as well. Corporate ethics is much required to emphasize the importance of sustainability, social development, stakeholders and consumers satisfaction. It brings to the notice of the business community the importance of honesty, sincerity and fairness making them alert, socially upright and pacifies conflicting interest of various sections of the society and accelerating better relation between business and the society. Business ethics levels can be exhibited as follows:

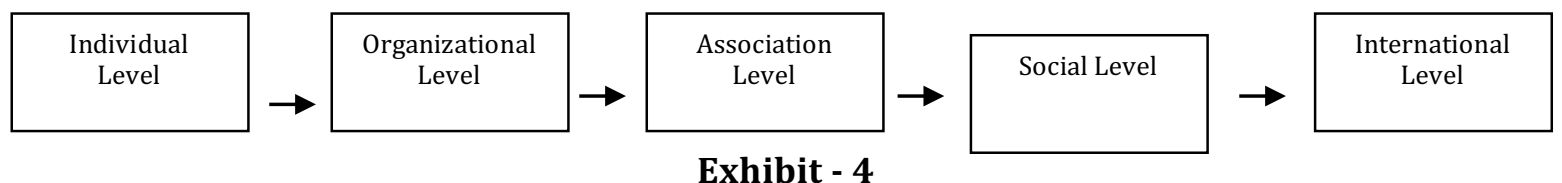

Individually and collectively acting with integrity, the board helps regulate and determine the efficaciousness of ethical corporate behavior in the corporation and in the wider society at large [14]. However, there are certain myths about business ethics. The popular myths are presented as follows: 


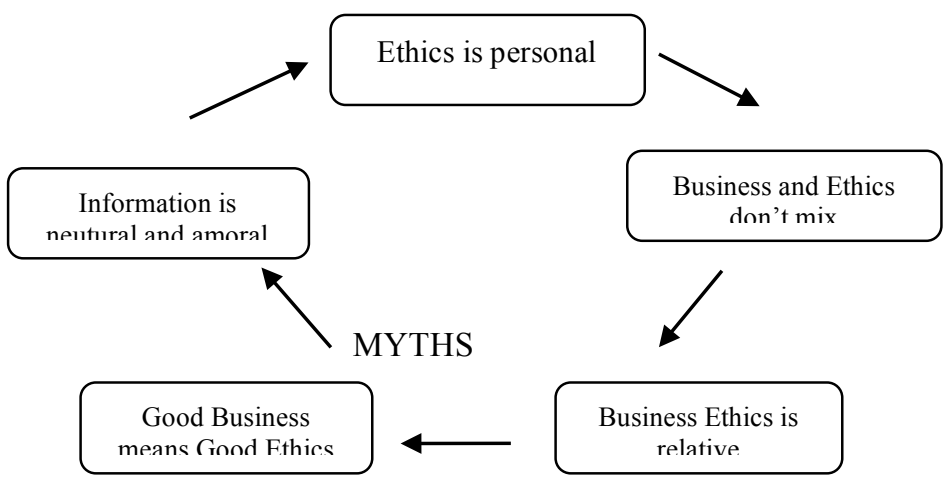

Exhibit-5

Success of an ethics programme depends on: i) leadership; ii) consistency between words and actions; iii) fairness; iv) rewards and v) value drive.

Model code of business conduct and ethics includes the following : i) contributing to society and human well being; ii) avoiding harm to others; iii) being honest and trustworthy; iv) being fair in taking action to discriminate; v) honoring confidentiality; vi) possessing professional responsibilities; vii) striving to achieve the highest quality, effectiveness and dignity in both the processes and products of professional work; viii) acquiring and maintaining competence; ix) knowing and respecting existing laws; $\mathrm{x}$ ) accepting and providing appropriate professional review; xi) managing personal and resources to enhance the quality of working life; xii) dealing with the media tactfully; xiii) being straight; xiv) observing corporate discipline; xv) conducting ourselves in such manner that reflects credit to the company; xvi) accountability to stakeholders; xvii) identifying, lessening and managing business risks; and xviii) protecting the company's properties.

\section{THIRD PHASE}

\section{Corporate Governance in India and Issues}

\section{INDIAN SCENARIO}

Although Indians are considered sharp-witted businessmen globally, they are not considered as honest. In the post-independence era, businessmen started cheating and corruption. Private firms pay scant attention to the age-old values of honesty and uprightness and fleeced shareholders, investors, employees and other stakeholders but public sector undertakings enjoying protected and monopolistic positions are carried on with atrocious misgovernance and passed on the costs to customers. Unethical practices concerning industrial licenses, import licenses, money abroad, corruption culture, tax evasion, scandals, etc. were observed due to fact that they happened in an atmosphere that encouraged corruption. Transparency and accountability, the two pillars of corporate governance were hidden merely on the ground of state security and obscurantist philosophy of socialism. Ever since India's high profile corporate fraud and governance failure unearthing Satyam scam, UTI scam, Ketan Parikh scam, etc. has called for a need to make corporate governance in India transparent as it badly affects the development of the country. Internationally, there has been a great deal of debate going on for quite some time. The Japanese business culture does not depend on overtly legislative and legalistic bodies; rather, it depends on social values. Business is their part of life, not a separate thing. 


\section{Objectives of Corporate Governance in India}

Transparency in corporate governance is essential for the growth, profitability and stability of any business. The need for good corporate governance has intensified due to growing competition amongst businesses in all economic sectors at the national, as well as international level.

\section{Importance of Corporate Governance in India}

Corporate having good corporate governance has much higher level of confidence amongst the shareholders associated with that corporate. Active and independent directors contribute towards positive outlook of the corporate in the financial market influencing share prices. Corporate governance, one of the important criteria helps foreign institutional investors select ./ company to invest in. Corporate practices in India emphasize the functions of audit and finances having legal, moral and ethical implications for the business and its impact on the shareholders. The Indian Companies Act, 2013 has introduced innovative measures to appropriately balance legislative and regulatory reforms for the growth of the corporate and increase foreign investment keeping in mind international practices and transparency in corporate governance which ultimately safeguards not only the management but also the interests of the stakeholders as well and fosters the economic progress of India in the roaring economies of the world.

\section{Need for Corporate Governance}

Corporate governance suffered because corporations mistook the shibboleths of responsibility and a lot of best practices that were attached to the reports sent to the regulators as corporate governance. From 2008 onwards, corporate governance failed because at a time when people felt support and confidence from corporation, the corporations just shirked every responsibility, lay off employees, and let the nation drown in debt. Freedom of free market was used wrongly and credit was allowed to inflate, to make people live beyond their dreams, by creating false dreams and smashing hopes for generations to come. Board of directors having entrusted with the power of governance is at the apex of the body of the company. However, the status of the directors is very high and could be easily amenable to malpractices. The main reason for the financial crisis is lack of transparency and accountability. The need for corporate governance is highlighted by the following factors:

(i) Wide spread of shareholders: Now-a-days, due to large number of shareholders spread around the world and a majority of shareholders being unorganized and having indifferent attitude towards corporate affairs, the idea of shareholders' democracy remains confined only to the law and the Articles of Association requiring practical implementation through a code of conduct of corporate governance.

(ii) Changing ownership structure: With changes in the pattern of corporate ownership, institutional investment (foreign as well Indian) and mutual funds becoming largest shareholders in large corporate private sector the investors have become the biggest challenge to corporate managements, forcing the latter to abide by some established code of corporate governance to build up its image in society.

(iii) Corporate scams or scandals: Corporate scams (or frauds) in the recent past have lost public confidence in corporate management. The event of Harshad Mehta scandal, probably the one biggest scandal is in the heart and mind of all and is concerned with corporate shareholding or otherwise being educated and socially conscious. The need for corporate governance is, then, imperative for reviving investors' confidence in the corporate sector towards the economic development of society. 
(iv) Greater expectations of society: Modern society expects more from the corporate sector in terms of reasonable price, better quality, pollution control, best utilization of resources etc. There is a need for code of corporate governance for the best management practices of company in economic and social terms to meet economical expectations.

v) Hostile take-over: Hostile take-over of corporations witnessing in several countries put questions about the managerial efficiency of take-over companies. This factor also points out to the need for corporate governance in the form of an efficient code of conduct for corporate management.

(vi) Huge increase in top management compensation: In both the developing and developed economies, there has been a huge increase in the monetary payments (compensation) packages of top level corporate executives having no justification for exorbitant payments out of corporate funds which are the properties of shareholders and society. This factor necessitates corporate governance to contain ill-practices of top management of corporate.

(vii) Globalization: More and more Indian companies desirous to get listed on international stock exchanges also focus on the need for corporate governance. In fact, corporate governance has become a buzzword in the corporate sector. There is no doubt that international capital market recognizes only well-managed corporate according to standard code of corporate governance.

\section{Corporate Governance Initiatives in India}

In India, corporate governance initiatives have been undertaken by the Ministry of Corporate Affairs (MCA) and the Securities and Exchange Board of India (SEBI). The first formal regulatory framework for listed companies specifically for corporate governance was established by the SEBI in February 2000, following the recommendations of Kumarmangalam Birla Committee Report. It was enshrined as Clause 49 of the Listing Agreement. By mid-2003, all the listed companies came under SEBI and the code. The root cause for such a paradigm change in the Indian industry was clearly due to the changed atmosphere of the economic reforms. Corporate had to regulate them because the shareholders base widened appreciably every quarter. However, SEBI still does not have enough statutory powers to act more conclusively and effectively. Corporate governance is primarily the separation of ownership from governance, so that a corporate may be governed independently of the promoters and professionally in keeping with the best practices. Further, SEBI is maintaining the standards of corporate governance through other laws like the Securities Contracts (Regulation) Act, 1956; Securities and Exchange Board of India Act, 1992; and Depositories Act, 1996.

MCA appointed Naresh Chandra Committee on Corporate Audit and Governance in 2002 to examine various corporate governance issues. It made recommendations in two key aspects of corporate governance: financial and non-financial disclosures; and independent auditing and board oversight of management. It is making all efforts to bring transparency in the structure of corporate governance through the enactment of the Companies Act and its amendments. With the objective of promoting better corporate governance practices in India, MCA has set up National Foundation for Corporate Governance (NFCG) in partnership with Confederation of Indian Industry (CII), Institute of Company Secretaries of India (ICSI) and Institute of Chartered Accountants of India (ICAI). The Indian approach is drawn from the Gandhian principle of trusteeship and the Directive Principles of the Indian Constitution. 


\section{Regulatory framework on Corporate Governance}

The Indian statutory framework has, by and large, been in consonance with the international best practices of corporate governance. Broadly speaking, the corporate governance mechanism for companies in India is enumerated in the following regulations agreement:

i. The Companies Act, 2013: This Act inter alia contains provisions relating to board constitution, board meetings, board processes, independent directors, general meetings, audit committees, related party transactions, disclosure requirements in financial statements, etc.

ii. SEBI Guidelines: SEBI is a regulatory authority having jurisdiction over listed companies and which issues regulations, rules and guidelines to companies to ensure protection of investors.

iii. Standard Listing Agreement of Stock Exchanges: For companies listed on the stock exchanges.

iv. Accounting Standards issued by the Institute of Chartered Accountants of India (ICAI): ICAI is an autonomous body which issues accounting standards providing guidelines for disclosures of financial information. Section 129 of the New Companies Act inter alia provides that the financial statements shall exhibit true and fair view of the state of affairs of the company and comply with the accounting standards notified u/s 133 of the New Companies Act. It is further provided that items contained in such financial statements shall be in accordance with the accounting standards.

v. Secretarial Standards issued by the Institute of Company Secretaries of India (ICSI): ICSI is an autonomous body which issues secretarial standards in terms of the provisions of the New Companies Act. So far, the ICSI has issued Secretarial Standards on "Meetings of the Board of Directors" (SS-1) and Secretarial Standards on "General Meetings" (SS-2). These Secretarial Standards have come into force w.e.f. 01/07/ 2015. Section 118(10) of the Act provides that every company (other than one person company) shall observe Secretarial Standards specified as such by the ICSI with respect to general and board meetings.

\section{Corporate Governance in Companies Act, 2013}

The Indian Companies Act, 2013 has introduced some progressive and transparent processes benefitting stakeholders, directors as well as the company management. Investment advisory services and proxy firms provide concise information to the shareholders about these newly introduced processes and regulations aiming to improve the corporate governance in India.

Corporate advisory services are offered by advisory firms to efficiently manage the activities of companies to ensure stability and growth of the business, maintain the reputation and reliability for customers and clients in the interest of the company and minority shareholders. Corporate governance ensures strict and efficient application of management practices along with legal compliance in the continually changing business scenario in India. Corporate governance was guided by Clause 49 of the Listing Agreement before introduction of the Companies Act, 2013. As per the new provision, SEBI has also approved certain amendments in the Listing Agreement to improve the transparency in transactions of listed companies and giving a bigger say to minority stakeholders in influencing the decisions of management w.e.f. $01 / 10 / 2014$.

One of the important areas of corporate governance introduced in the Companies Act, 2013 is: 1. Independent Director: Under the Companies Act, 2013 the strength of number of independent directors for the prescribed companies u/s 149(4) read with Rule 4 of Companies (Appointment and Qualifications of Directors) Rules, 2014 is as follows: 


\author{
Listed Public Company \\ Public Companies having turnover of 100 \\ crores rupees or more \\ Public companies having paid up capital of 10 \\ crores rupees or more
}

\section{At least one third of total number of directors}

At least 2 directors

At least 2 directors

Woman Director: Section 149 (1) of the Companies Act 2013 prescribes the following classes of companies to have at least one woman director:

i) All listed companies: ii) Non-listed public companies having paid up share capital of Rs.100 crores or more or having turnover of Rs.300 crores or more.

Audit Committees: The Companies Act, 2013 has increased the ambit of companies to constitute audit committees. The constitution of audit committee has also seen change as compared to clause 49 with minimum three independent directors. The Chairperson should be able to read and understand the financial statement. It shall be applicable to all the listed companies or non-listed public companies having paid up share capital of Rs.10 crores or more, Turnover of Rs. 100 crores or more, aggregate outstanding loan of Rs. 50 crores or more.

Serious Fraud Investigation Office (SFIO): SFIO established u/s 211 (1) of the Companies Act, 2013 will investigate fraud relating to the affairs of company or on receipt of report of Registrar or Inspector or in the public interest or request from any Department of Central Government or State Government.

Corporate Social Responsibility: Section 135(1) of Companies Act, 2013 prescribes that every company shall constitute Corporate Social Responsibility Committee constituting of three or more directors with at least one independent director. These companies include companies having net worth of Rs. 500 crores or more turnover of Rs. 1000 crores or more or net profit of Rs.5 crores or more during any financial year.

\section{A Few New Provisions for Directors and Shareholders}

i) One or more women directors are recommended for certain classes of companies; ii) Every company in India must have a resident director; iii) Maximum permissible directors cannot exceed 15 in a public limited company. If more directors have to be appointed, it can be done only with approval of the shareholders after passing a Special Resolution; iv) The Independent Directors are a newly introduced concept under the Act. A code of conduct is prescribed and so are other functions and duties; v) The Independent directors must attend at least one meeting a year; vi) Every company must appoint an individual or firm as an auditor. The responsibility of the Audit Committee has increased; Filing and disclosures with the Registrar of Companies has increased; vii) Top management recognizes the rights of the shareholders and ensures strong co-operation between the company and the stakeholders; viii) Every company has to make accurate disclosure of financial situations, performance, material matter, ownership and governance.

\section{Additional Provisions}

i) Related Party Transactions - A Related Party Transaction (RPT) is the transfer of resources or facilities between a company and another specific party. The company devises policies which must be disclosed on the website and in the annual report. All these transactions must be approved by the shareholders by passing a Special Resolution as per the Companies Act, 2013. Promoters of the company cannot vote on a resolution for a related party transaction; ii) Change in Clause 35B - The e-voting facility to be provided to the 
shareholders for any resolution is a legal binding for the company; iii) Corporate Social Responsibility - A company has a responsibility to promote social development in order to return something beneficial for the society; iv) Whistle Blower Policy - This is a mandatory provision by SEBI which is a vigil mechanism to report the wrong or unethical conduct of any director of the company.

\section{FOURTH PHASE}

\section{SUGGESTIVE MEASURES}

Casual measures as a piecemeal fashion are not sufficient to arrest corporate corruption. Applying and integrating ethical values and concepts with day-to-day activities through organizational environment is a more effective approach in this direction. Ethics has conceptual understanding of normative science, conduct, society and right/wrong. Ethics of individual's conduct and ethics of business entity's conduct should have different criteria. Individual's conduct is guided by desires, ideas, unconscious mental tendencies, sense of duty, etc. whereas business conduct is guided by aims and objectives of the organization, collective ambitions and judgments of managers, expectations of stakeholders, etc. Both business conduct and individual's conduct is well arrested by the social customs and preferences [15]. However, the entire practices can be fruitful with the help of cultivation of ethics in both theory and practice by the top management level, establishment of code of ethics as a part of company policy, use of ethics committee, teaching of ethics in management training and development programmes and conducting ethics audit. Ethics being normative science involves various concepts like values, conscious, social norms, expectations of society etc. For elevating ethics amongst others, moral education gets topmost priority. Besides, we have to take decision in the interest of the vast community instead of narrow interests.

Business community may get its accepted behavior written down and codified and can periodically revise its norms and force its members to obey these. Business associations can play a very constructive role at this level. Codification of ethical practices will establish trustworthiness and understanding and in the long- run will promote international business. Management and other professional course institutions must include some input in relation to ethics for business. Many management institutions have already included concepts on ethics in the formal MBA curriculum. Eminent thinkers and speakers including some industrialists having practices ethical conduct may be invited to deliver speech on ethics in business to budding managers. Corporate consciousness has relevance particularly among top executives in the context of increasing doubts about the honesty of the boards of large corporate in India. Various working groups and committee reports have also laid down principles towards customers, competitors, employees, owners, suppliers and lastly towards communities. Code of conduct prepared by business organizations improves ethics and reduces corruption and uncertainty. Cadbury Committee [16] set up in May 1991 by the London Stock Exchange and chaired by Sir Adrian Cadbury has also suggested that board should pay adequate attention to their duties to present a balanced and understandable assessment of their corporate position. In the proposal, the responsibility of directors, executives are made more binding and disclosure norms more progressive and detailed. Abt Associates, a management consultancy firm of USA has suggested that in line with conventional statements, there should be social income statements and balance sheet also in which social benefits and social costs, and social assets and social liabilities are to be incorporated. Indian concept of trusteeship has Indian ethos and has greatly influenced Indian executives of past and present in being of highest ethical conduct. Sections 407 to 434, section 132 and section 211 of the Indian Company's Act, 2013 provide for constitution of several regulatory bodies like National Company Law Tribunal (NCLT), National Financing Reporting Authority (NFRA), Serious Fraud Investigation Office 
(SFIO) to deal with the matters, issues, disputes, supervision, regulation of the activities of auditors and companies. Section 134(5) (e) of the 2013 Act lays down very wide responsibility regarding internal financial control reporting on the directors, strategic and operational aspects of the business and the efficiency thereof. Section 143(12) of the Act also requires that in the course of the performance of auditor's duties if an auditor finds that an offence involving material frauds is being or has been committed against the company by its directors or employees, the auditor will immediately report the matter in prescribed Form ADT-4 to the Central Government within the prescribed time and manner. The provisions will also apply to a cost auditor and secretarial auditor. Non-compliance with this requirement knowingly and willfully is punishable with a fine of minimum Rs. 1 lakh which may extend to Rs. 25 lakhs.

With the introduction of the Corporate Social Responsibility Voluntary Guidelines in 2009 by MCA, Section 135 of the 2013 Act seeks to provide constitution of the Corporate Social Responsibility (CSR) Committee of the board and makes it mandatory to spend at least 2\% of the average net profit of the immediately preceding three years on CSR activities, otherwise, explanation for the reasons thereof is required to be incorporated in the Director's Report. The committee is entrusted to formulate policies including various activities specified in Schedule VII under certain circumstances. We have to change our national culture. Trust-the most important business asset is created by doing right thing. Corporations are expected to build a better future for the wider world.

\section{FINAL PHASE}

\section{CONCLUSION}

As far as structural and regulatory changes are concerned, India has witnessed several enactments - the Companies Act, 2013 and SEBI's listing obligations and disclosure regulations having significance to strengthen governance norms and increase accountability. For achieving desired results, it is important to model regulatory measures based on the practices and business environment in India. Although ethics is an integral part of governance, corporate sectors in India have not achieved much success. "Corporate Governance and Business Ethics" have created anxiety in these sectors. With increasing international trade, we need to develop methodical approach towards ethics so that there is greater credit worthiness for our organizations and less stressful experiences for corporate executives. Top managers should establish themselves good examples of ethical practice in the organization to ensure ethical values. Corporate in India have also started understanding its importance to conduct business without compromising on principles or corporate ethical responsibilities to gain benefits and long- term survival. Adherence to strong ethics policy is likely to enjoy a long-term competitive advantage because the ethical reputation of a corporate doesn't necessarily lead to new performances, but non-ethical reputation may seriously affect future performance or the development of new businesses. Effective corporate governance based on core values of integrity and trust can gain much competitive advantage which attracts and retains best multiple alternatives and generates positive reactions in the market place. Any corporate getting reputation for ethical behavior in this competitive market place engenders not only customer loyalty but also employee loyalty. Corporate must make profit to survive and grow but the pursuit of profit must stay within ethical bounds pursuing policies that involve environmental protection, whistle blowing, ethical training programs and so on. Such compliance mechanisms help develop and build corporate image, gain trust from consumers and heighten commitment to employees. Focus of the virtues in governance is to establish a series of practical responses depending on the consistent application of core values and principles as well as commitment to ethical business practice. Setting up of code of ethics, ethics committees and ethics audits can go a long way in building an organizational 
environment fostering ethical behavior and decision making in corporate. Acting ethically in the business decision making process will ensure more effective and productive utilization of economic resources and institutional improvement which can also influence on the society as a whole. Ethics is the first line of defense against corruption while law enforcement is remedial and reactive. Sound corporate governance practices cannot guarantee success always, but the absence of such governance definitely leads to questionable practices, debate and even failures. Well established corporate governance provides environment where corruption will certainly wither and enable a corporation to compete more efficiently and prevent wrong doings and imposture within the organization.

There have been mixed reactions to the introduction of the "spend or explain" approach taken by the MCA with respect to CSR. It may take time before all corporate cultivates CSR as a culture. The 2013 Act have far reaching implications and are all set to considerably change the manner in which the corporate operate in India. The most important challenge it claims is transition of the corporate to comply with the provisions of the 2013 Act from the accustomed 1956 Act. We can only hope the Government provides appropriate technique for such transition and the 2013 Act is able to produce better corporate governance among the corporate which will accelerate the progress of the Indian economy.

\section{RESEARCH OPPORTUNITIES}

Since the researcher mostly collects data in the officially communicated corporate governance and business ethics on the firm's official websites, none of the other sources have been examined in this study. The study being confined to India, it discusses only the perspective of India's corporate governance. For future research, more developing and developed countries can be compared to see the impacts of reforms of corporate governance practices. Further, this paper discusses only two of the influencing factors of corporate governance i.e. ethics and internal governance; other factors influencing corporate governance can enrich this study too. More research can be done to see how firms from countries like India affect the corporate governance of other countries as they develop new relations abroad. Pursuing the emerging frontier of corporate governance with ethics is a platform for new research and new techniques that if implemented effectively, can generate more equitable global business environment.

\section{CONCLUDING COMMENT}

Corporate governance and ethics being hard to differentiate in the global economic landscape, their convergence in the face of regulatory, business and social transformation in transnational markets has evoked debate and controversy over corporate accountability. Corporate with good governance has much higher level of confidence amongst the shareholders. Corporate practices in India emphasize the functions of audit and finances having legal, moral and ethical implications for the business and its impact on the stakeholders. The Companies Act, 2013 has introduced innovative measures to appropriately balance legislative and regulatory reforms for the growth of corporate and to increase foreign investment keeping in mind international practices. Corporate governance safeguards not only the management but the interest of the stakeholders as well and fosters the economic progress of India in the roaring economies of the world.

\section{ACKNOWLEDGEMENT}

This paper is devoted to ALMIGHTY GOD who always inspires me in writing the paper. 


\section{References}

Donaldson, John \& Fafaliou, Irene, Business Ethics, Corporate Social Responsibility and Corporate Governance: A Review and Summery Critique, European Research Studies, 2003.6 (1-2): p. 90.

M. Bhasin, Audit Committee Mechanism to Improve Corporate Governance: Evidence from a Developing Country, Modern Economy, 2012. 3(7): p. 856-872.

S. Claessens and B. Yurtoglu, Corporate Governance in Emerging Markets: A Survey, Emerging Markets Review, 2013. p. 151-33.

S. L. Gillan, Recent Developments in Corporate Governance: An Overview, Journal of Corporate Finance, 2006. 12: p. 381-402.

K. Han and Y. Lu, Corporate Governance Reforms Around the World and Cross-Border Acquisitions, Journal of Corporate Finance, 2013.

V. C. Joseph and L. N. Terry, Audit Committee Characteristics and Auditor Dismissals Following "New" GoingConcern Reports, Jan, 2003. The Accounting Review, 78, (1): p. 95-117.

S. Li and A. Nair, Asian Corporate Governance or Corporate Governance in Asia? Corporate Governance: An International Review, 2009. 17 (4): p.407-410.

C. S. V. Murthy, Business Ethics and Corporate Governance, 2009. Global Media, Mumbai, India.

S. B. Young, The Ethics of Corporate Governance, the North American Perspective, International Journal of Law and Management, 2009.51(1).

Schwartz, M, The State of Business Ethics in Israel: A Light unto the Nations? J Bus Ethics, 2012. 105: p.429-446.

Rao, P. Mohana, Corporate Governance - An Analytical View, Corporate Social Accounting and Reporting, 1999. Deep \& Deep Publications Pvt. Ltd., New Delhi: p. 257.

Vishwakarma, R., Corporate Governance and its Attributes: An Explotary Study of MFIS, Research Bulletin, October 2016.The Institute of Cost Accountants of India, Kolkata, 42(3).

Albuqnerque, Daniel, Business Ethics, Principles and Practices, 1st edition ed 2010. Oxford University Press, New Delhi, p. 373.

Christine, A. Mallin, Corporate Governance, 3rd edition ed2010.0xford University Press, New Delhi, p. 369.

Jain, T.K., Ethics in Business, Corporate Social Accounting and Reporting, 1999. Deep \& Deep Publications Pvt. Ltd., New Delhi, p. 264.

Adrian Cadburg, Developments in Corporate Governance, The Chartered Secretary, May 1997. p. 487-490. 